Sociološki pregled, vol. XXXV (2001), no. 1-2, str. 163-166.

ПОЛЕМИКА

\title{
Зоран Аврамовић
}

Институт за педагошка

истраживања

Београд

\section{КО ЈЕ НАЈБОљИ НАУЧНИК У ПОЛИТИКОЛОГИЈИ}

(Слободан Антонић: "Избори, странке, демократија", Сочиолошки преглед, 3-4, 2000)

Текст С. Антонића је објављен као приказ књиге али по садржају изазива критички осврт бар из два разлога. Више од половине приказа "бави" се односима у научној заједници Републике Србије на примеру др Владимира Гоатија. Та тема је потпуно скрајнута у српском научном животу, а низ институционалних и кадровских решења у науци нашег друштва врти се око персонално-клановских груписања и повезивања. У српској социјалној науци, у искуству генерација социјалистичког самоуправљања и социјалистичког парламентаризма (као и почетно искуство досовског парламентаризма) белодано влада приватно кадровско котеријаштво над аутономним и стручним критеријумом. Отуда, разлог да се полемички размотре неке оцене С. Антонића. Други разлог за овај критички осврт је начин на који се прави навијачка научна критика. Није реч о сумњи у моралне и теоријске мотиве С. Антонића већ о резултату његове критике који су типичан пример непокривене и неутемељене хвале једног дела и његовог творца (др Владимира Гоатија).

Да размотримо најпре "несрећну" научну каријеру др Владимира Гоатија. Антонић тврди да је Гоати био "поприлично запостављен" од Факултета политичких наука у Београду и да је био "трн у оку" како идеолошки правоверним "политиколозима" и марксистичко-опозиционим интелектуалцима. Не сећам се да је Гоати био "трн у оку" социјалним теоретичарима и истраживачима у протеклих двадесет година. Али, свако се добро сећа да је Гоати био члан аналитичког штаба Савеза комуниста Србије и да је на разне начина учествовао у стварању и наметању комунистичке идеологије током владавине партијске државе у СФРЈ. Та чињеница је од великог значаја за разумевање неколико научних генерација у Србији чији је Гоати само један пример. Она омогућава објашњење: 1) кадровске ситуације на високошколским установама у социјалистичком самоуправљању и 2) нова политичка и научна понашања после 1990.

Зашто се Антонић чуди због "прикраћене" каријере Владимра Гоатија. У време комунистичког монопола сва кадровска решења, па и она на универзитету била су у рукама комунистичке партије. Унутар идеолошке породице 
било је свађа и сукоба, котерија, кланова и целу заврзламу с Гоатијем треба посматрати у том идеолошко политичком контексту. Зашто би неко жалио за једим поразом па био он и идеалан у научном постигнућу. Питање треба поставити: зашто је спречен у научној или професорској каријери онај који није припадао комунистичкој идеолошкој породици? То је право питање, а не зашто је један клан победио у кадровској игри над другим. Сви они који су стварали комунистички обруч око вредности и знања немају моралног права да се жале на своју "несрећну" судбину. То право припада само онима који су оспоравали идеологију политичког монопола и због тога нису ни у сну могли да буду професори у образовним установама.

Необично је да Антонић на две стране покушава да докаже како су идеолошки научници преписивали Гоатија. Реч је о преписивању референци из књиге Политичка социологија (сам наслов је проблематичан - ваљда социологија политике. Овако би свака делатност могла да буде социологија). Слабе је доказне снаге тврдња за плагијат. У нашој науци се и данас дословно преписују реченице и странице па ником ништа.

Друга импликација случаја Владимира Гоатија је општа и морално поразна за научни живот у Србији. Ради се о некој врсти научног конвертитства. Низ научника социјалних знања, оних који су били на стражи идеологије комунистичког монопола, преко ноћи су се преокренули у идеологе вишестраначког поретка и прешли на страну "опозиције" а против бивших сабораца. Наши научници и професори који су више деценија разрађивали основне идеје комунизма избраздали су своју менталну матрицу. Тај начин мишљења се подстицао, награђивао, популарисао. С догађајима из 1989 наступа другачије мишљење, из основа супротно једнопартијском социјализму. Да ли је могућно да они који су деценијама мислили у једној матрици сада почну да мисле на нов начин. Могућно је, али мало вероватно. Само ретки успевају да одбаце старо одело. Највећи број само навлачи ново на старо. Кривац за то је дугогодишњи ментални тренинг. У ту категорију научника спада и Гоати. Колико се пута појавио у новинама као "опозиционар"? Колико пута је "опалио" по онима који су били другови у грађењу комунистичке утопије. Свако ко је знао историју српске науке у последњих тридесет година морао се упитати за разлоге научног конвертитства. Најслабија је претпоставка о научном развоју, о унутрашњим научним потребама, а најјача она о материјалним наградама из разних светских фондова. Потребно је проверити ове претпоставке.

Када је затамнио ову страну научне каријере Антонићу је било лако да у некој необјашњивој претераности прогласи Гоатија за највећег научника политичких питања у Србији током 80-тих и 90-тих година. Тешко је разумети тврдњу да политички научник у данашњој Србији може бити добар само ако је и сам "гоатијевац" - као што Антонић недвосмислено тврди. Тешко, стварно тешко. За такву титулу је потребно низ дебелих доказа - стручних, моралних, организацијских. 
Sociološki pregled, vol. XXXV (2001), no. 1-2, str. 163-166.

О моралним и организацијско-конвертитских било је речи. О стручним сам Антонић наводи контраргументе у рецензији две најновије књиге. (У некој другој прилици радо бих обновио своју анализу књиге Политичка соииологија од пре две деценије).

Антонић тврди да су књиге В. Гоатија- Избори у СРЈ од 1990 до 1998 и Партије Србије и Црне Горе у политичким борбама од 1990 до 2000. досад најбољи списи из "примењене" политичке социологије. Зачудо, критички осврт на две поменуте књиге показује нешто сасвим супротно. Примедбе су такве да у великој мери демантују неучне суперлативе упућене на адресу В. Гоатија. Антонићева критика показује већ одраније познате недостатке Гоатијевог научног мишљења - неутемељено теоријско мишљење и идеолошки однос према емпиријским подацима, при чему реч идеолошки треба схватити као прилагођавање својим политичким жељама и интересима, а мање некој политичкој партији.

Већ десет година Гоати тврди да демократија у Србији заостаје у односу на друге републике бивше СФРЈ због оданости становништва Србије "ауторитарном комунизму". Гледајући с историјског становишта оваква тврдња изазива осмех. Србија која има најдужу државну традицију на простору бивше југословенске државе каска у демократији за онима којима је држава наметнута или поклоњена пре неколико година. Са становишта социологије и политике тврдња је нетачна због природе српског аграрног друштва (сеоски посед и под страним окупацијама) а треба подсетити на чињеницу да је у Србији пружан најжешћи отпор титоизму и комунистичком монополу током 70-тих и 80-тих година (О томе сам писао у књизи Друго лище демократије).

Необично је да Гоати, који је био теоретичар комунистичке партије критикује вишестраначки политички поредак у Србији ("ауторитарни поредак у Србији") због права странака да одређују посланике у скупштинским установама. О партијама се може свашта писати, али представник народне воље може бити члан странке или независни грађанин. Бирачи поклањају поверење странци или независним кандидатима. У првом случају право је странке да подели мандате (М. Вебер). То право је максимално искористио ДОС на изборима 2000. када су бирачи заокруживали листу ДОС-а . Да ли је и то био израз ауторитарног поретка?

Какав је однос В. Гоатија према чињеницама говори и његова тврдња о односу власничке структуре у привреди Црне Горе и Србије. Противно економским показатељима о скромној приватизацији у Црној Гори, он шири "истину" о демократској Црног Гори и недемократској Србији као детерминанти власничке структуре.

Да емпиријски подаци не обавезују Гоатија показује и његова теза да су грађани Србије показивали неповерење према политичким промена особито према "плуралистичком поретку". Проценат изласка на изборе као један од критеријума заинтерсованости грађана за политички живот показује висок проценат (средина у односу на бивше републике СФРЈ). Упркос таквим пода- 
цима он изводи тврдњу, ни мање ни више, да су грађани Србије неповерљиви према политичком плурализму!!

Вратимо се на теоријски терен, на теоријску дескрипцију. И ту Гоати показује своју личну а не научну заинтересованост за политичку слику Србије и Црне Горе. Његова приватна класификација странака у Србији и Црној Гори показује да у Србији делују комунисти (СПС и ЈУЛ) а у Црној Гори социјалисти. У Србији делују националисти (СРС, СПО, ДСС) а у Црној Гори либерали (као да је реч о наследницима Џ.С. Мила). Испада да у Црној Гори нема комуниста и националиста а Србија врви од остатка идеолошке прошлости. Испада да је црногорски ултрасепаратизам либерала ненационалистички, а у Србији политички програм очувања државе и нације на окупу и у заједници, ништа друго до национализам! Необично, нема шта! Уосталом, као неко ко се бавио и демократијом, морао би да зна да су његове класификације вредносно-програмског карактера, а да ли је странка демократска или не проверавамо у практичном придржавању процедуралног легитимитета. Критеријум проауторитарне и продемократске странке важи превасходно за њене унутрашње односе, а недовољан је за оцену политичког поретка.

Ето, то је кратка прича о В. Гоатију. Он је само добар пример за идеологизацију и материјализацију конвертитског научног сазнања, за политички опортунизам научника и за необјективно произвођење у класике. Прича би могла да буде дужа и богатија у садржају, али то сада није потребно. Ова кратка "критика критике" написана је у жељи да се подстакне разговор о стању и односима у нашој социјалној науци. Она је бременита наслеђем идеолошке прошлости а нови односи у српској науци се тешко успостављају. Идеолошке котерије из самоуправног социјализма замењене су клановима који приватизују државне образовне и научне установе при чему шире везе с иностраним финансијерима науке и образовања. Тако, политичка опредељења добијају ауру научних сазнања. Тешко је рећи да ли у времену у коме живимо наука има шансу да остане независна од политичких и материјалних интеpeca. 